\title{
The molecular diversity of arbuscular mycorrhizal fungi in the arsenic mining impacted sites in Hunan Province of China
}

\author{
Yuqing Sun ${ }^{1,2}$, Xin Zhang ${ }^{1}$, Zhaoxiang $\mathrm{Wu}^{1,2}$, Yajun $\mathrm{Hu}^{1,2}$, Songlin $\mathrm{Wu}^{1,2}$, Baodong Chen ${ }^{1, *}$ \\ 1. State Key Laboratory of Urban and Regional Ecology, Research Center for Eco-Environmental Sciences, Chinese Academy of Sciences, Beijing \\ 100085, China. E-mail: yuqing_110226@163.com \\ 2. University of Chinese Academy of Sciences, Beijing 100049, China
}

\section{A R T I C L E I N F O}

Article history:

Received 23 July 2015

Revised 5 October 2015

Accepted 6 October 2015

Available online 7 December 2015

Keywords:

Arsenic pollution

Arbuscular mycorrhizal fungi

Biodiversity

454 pyrosequencing

Heavy metal

\begin{abstract}
A B S T R A C T
Arbuscular mycorrhizal fungi (AMF) can establish a mutualistic association with most terrestrial plants even in heavy metal contaminated environments. It has been documented that high concentrations of toxic metals, such as arsenic (As) in soil could adversely affect the diversity and function of AMF. However, there are still gaps in understanding the community composition of AMF under long-term As contaminations. In the present study, six sampling sites with different As concentrations were selected in the Realgar mining area in Hunan Province of China. The AMF biodiversity in the rhizosphere soils of the dominant plant species was investigated by sequencing the nuclear small subunit ribosomal RNA (SSU rRNA) gene fragments using 454-pyrosequencing technique. A total of 11 AMF genera were identified, namely Rhizophagus, Glomus, Funneliformis, Acaulospora, Diversispora, Claroideoglomus, Scutellopora, Gigaspora, Ambispora, Praglomus, and Archaeospora, among which Glomus, Rhizophagus, and Claroideoglomus clarodeum were detected in all sampling sites, and Glomus was the dominant AMF genus in the Realgar mining area. Redundancy analysis indicated that soil $\mathrm{pH}$, total As and Cd concentrations were the main factors influencing AMF community structure. There was a negative correlation between the AMF species richness and the total As concentration in the soil, but no significant correlation between the Shannon-Wiener index of the AMF and plants. Our study showed that high As concentrations can exert a selective effect on the AMF populations. C 2015 The Research Center for Eco-Environmental Sciences, Chinese Academy of Sciences.
\end{abstract}

Published by Elsevier B.V.

\section{Introduction}

Arsenic (As) is one of the most hazardous metalloid that can be released into the environment due to geochemical processes, e.g., rock weathering or volcanic eruptions (Fitz and Wenzel, 2002), or through anthropogenic activities, such as mining, application of biocides, and fossil fuel combustion, urban wastes discharging etc. (Mukhopadhyay et al., 2002; Beesley and Dickinson, 2010). Arsenic contamination could potentially cause global environmental problems and health risks (Smith et al., 1998; Meharg and Hartley-Whitaker, 2002).
As a result, As has been included in the list of 20 most hazardous substances by the Agency for Toxic Substances and Disease Registry (Dhuldhaj et al., 2013).

There are more than 300 As-bearing minerals, among which, realgar mine $\left(\mathrm{As}_{4} \mathrm{~S}_{4}\right)$ is less common (Hudson-Edwards and Santini, 2013). The Shimen Realgar Mine of Hunan Province in southern China, which had been mined for over 1500 years, had the largest source of realgar $\left(\mathrm{As}_{4} \mathrm{~S}_{4}\right)$ ore in Asia. Since 1958, large-scale mining activities, arsenic product processing with discharge of As-containing drainage, improper storage of tailings, and deposition of metallurgical fume,

\footnotetext{
* Corresponding author. E-mail: bdchen@rcees.ac.cn (Baodong Chen).
} 
gradually led to severe As contamination of the soil-water systems in the mining area. Arsenic can be taken up by plants and enter the food chain at excessive levels, thus possessing significant health risks to local people. Obviously, there is an urgent need to monitor the ecological impacts of As contamination and take effective measures to restore As-contaminated environments.

Many studies on As eco-toxicity focus on agricultural ecosystem and crops, but few on soil microbial communities in the natural ecosystems. As known, soil microorganisms play important roles in As biogeochemistry (Zhu et al., 2014; Wang et al., 2014), while soil contamination with As would greatly influence the biodiversity and function of soil microbial communities (Lorenz et al., 2006), and subsequently lead to a decrease of soil fertility. Arbuscular mycorrhizal fungi (AMF) are ubiquitous soil fungi in natural and agricultural ecosystems, and can form symbiotic associations with the majority of higher plants (Smith and Read, 2008). The AM (arbuscular mycorrhizal) association can essentially improve plant mineral nutrition (Willis et al., 2013), plant water relations (Li et al., 2013) and enhance plant resistance to As contaminations (Chen et al., 2007; Zhang et al., 2015). The ecological significance of AMF in stabilizing ecosystem structure and function has been widely accepted (van der Heijden et al., 1998; Rillig, 2004), and there is also a potential role of AMF in assisting bioremediation of As contaminated environments (Liu et al., 2005; Dong et al., 2008). Recent studies showed that AMF naturally occur in As-contaminated sites (Meharg and Cairney, 1999; Smith et al., 2010a). High As concentrations can exert a selective effect on the AMF populations, and reduce AMF species richness (Smith et al., 2010a; Schneider et al., 2012). AMF species are generally resistant to short-term As toxicity (Smith et al., 2010b), but may be changed under severe As contaminations. So far, little information is available about the AMF biodiversity in natural As-contaminated sites.

In the present study, we collected soil samples from the mining sites severely polluted by As in the Realgar mining area to detect the biodiversity of AMF by using 454-pyrosequencing technique. The study was aimed to test the impacts of As contamination on the AMF biodiversity, and to explore key factors influencing AMF community structure. It was expected that results from present study would deepen our understanding of the ecological impacts of As contamination, and also unravel the feasibility of isolating and introducing tolerant AMF in future ecological restoration programs.

\section{Materials and methods}

\subsection{Study area and sampling}

Soil samples were collected in October 2012 from Shimen Realgar Mine (N 29 $38^{\prime} 11^{\prime \prime}-29^{\circ} 38^{\prime} 43^{\prime \prime}, \mathrm{E} 111^{\circ} 2^{\prime} 06^{\prime \prime}-111^{\circ} 2^{\prime} 23^{\prime \prime}$ ) in Hunan Province of China. Based on the different pollution sources, six representative sites were selected and coded as REF, S1, S2, S3, S4, and S5, according to the total As concentration from low to high (Fig. 1). S1 and S3 located in the riverbank of Lishui River that was contaminated by the wastewater discharged from the tailing pool. S2 was situated in the As product processing factory. S4 was a slagheap, and S5 lied in the tailing pooled with mineral residue sediments. The site REF on

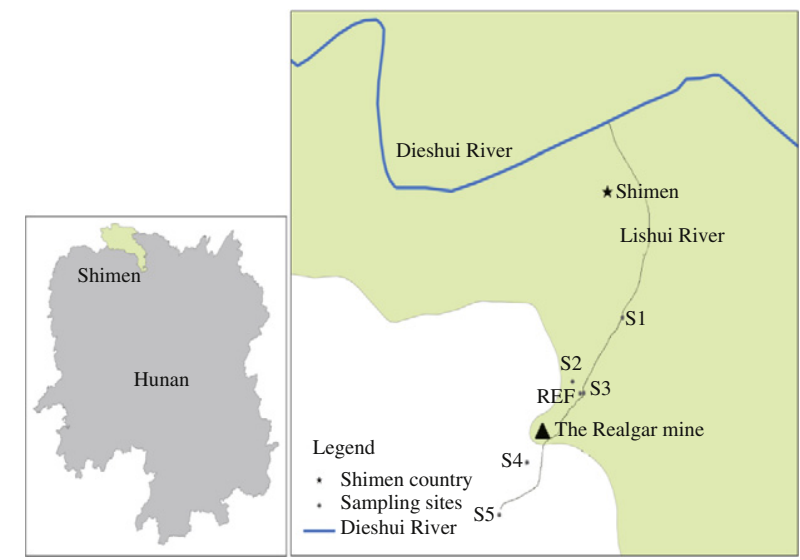

Fig. 1 - Map of the study area. REF, S1, S2, S3, S4 and S5 represent the six sampling sites.

another river bank that was almost parallel with the Lishui River, was chosen as an uncontaminated reference site.

Plant and soil samples were collected according to the methods described by Xiang et al. (2014). At each sampling site, four $1 \times 1 \mathrm{~m}^{2}$ quadrats were designated for vegetation survey. All plant species present in each quadrat were identified. The total number of individuals per plant species was counted. Ten soil cores (3 cm in diameter and $15 \mathrm{~cm}$ in depth) from each quadrat were taken, then mixed and stored in polyethylene bags at $4^{\circ} \mathrm{C}$ in a refrigerated box. After being transported to the laboratory, the composite soil samples were passed through a $2 \mathrm{~mm}$ sieve and divided into two subsamples. One subsample was kept at $-80^{\circ} \mathrm{C}$ for molecular analysis and the other was air-dried for analysis of soil physicochemical properties. The mixed roots were manually collected from the soil samples for measuring mycorrhizal colonization rates.

\section{Soil chemo-physical properties}

Soil $\mathrm{pH}$ was measured in a 1:2.5 (V/V) soil:water suspension. Soil available phosphorus (AP) was assayed according to the method described by Olsen (1954). Bioavailable As in the soil was extracted by $0.1 \mathrm{~mol} / \mathrm{L} \mathrm{HCl}$ (soil:solution = 1:10, V/W). Calculation of the soil $\mathrm{C} / \mathrm{N}$ ratio was based on the total $\mathrm{C}$ and total $\mathrm{N}$ contents that were analyzed using Element Analyzer (Vario EL III, Germany) (Xiang et al., 2014). Soil organic carbon (SOC) was assayed according to the Walkley-Black dichromate oxidation procedure (Nelson and Sommers, 1996).

Air dried soil samples were further passed through $0.15 \mathrm{~mm}$ sieve. Approximately $0.2 \mathrm{~g}$ sample was soaked in $10 \mathrm{~mL}$ $\mathrm{HNO}_{3}+2 \mathrm{~mL} \mathrm{HF}$ for $12 \mathrm{hr}$, then digested by CEM Mars 5.0 (CEM Co. Ltd., USA). The digested samples were analyzed for $\mathrm{Mg}, \mathrm{Mn}$, $\mathrm{Ni}$, Sb, Sn, Ti, Zn, Al, Ba, Cd, Fe, Bi, Co by inductively coupled plasma optical emission spectrometry (ICP-OES; Optima 2000 DV, Perkin-Elmer, USA) in $3 \% \mathrm{HNO}_{3}$, while the As concentration was measured by inductively coupled plasma mass spectrometry (ICP-MS; Agilent Technologies, 7500, USA) Blanks and internal standards of soil (GSS-6, China Standard Research Center) were used to ensure the accuracy of chemical analysis. All reagents were of analytical grade. 


\section{Microscopic and molecular identification of AMF}

The root samples were carefully cleaned and cut into $1 \mathrm{~cm}$-long segments and cleared in $10 \%(\mathrm{~W} / \mathrm{V}) \mathrm{KOH}$ solution at $90^{\circ} \mathrm{C}$ in a water bath for $30 \mathrm{~min}$, then acidified with $1 \% \mathrm{HCl}$ for $3 \mathrm{~min}$. Finally, the roots were stained with $0.05 \%$ (W/V) trypan blue for 30 min (Phillips and Hayman, 1970). Thirty randomly selected root segments were examined for intensity of mycorrhizal colonization (M\%) and the presence of arbuscules ( $\mathrm{A} \%$ ).

DNA was extracted from $500 \mathrm{mg}$ of freeze-dried and milled soil samples by using Fast DNA® Spin Kit for Soil according to the manufacturer instructions. Small subunit ribosomal RNA (SSU rRNA) gene fragments were amplified by nested polymerase chain reaction (PCR) with the primer pair of AML1/ AML2 (Lee et al., 2008). The PCR reactions were performed in a $25 \mu \mathrm{L}$ volume containing $2.5 \mu \mathrm{L} 10 \times E x$ Taq Buffer, $2 \mu \mathrm{L}$ $2.5 \mathrm{mmol} / \mathrm{L}$ dNTP mix, $1 \mu \mathrm{L} 50 \mathrm{ng} / \mu \mathrm{L}$ DNA template, $0.4 \mu \mathrm{L}$ $25 \mu \mathrm{mol} / \mathrm{L}$ each of forward and reverse primers, $0.25 \mathrm{U}$ TakaRa Ex Taq (TaKaRa, Dalian, China) and $18.45 \mu \mathrm{L}$ of sterilized deionized water. The first PCR program was as follows: initial denaturation at $94^{\circ} \mathrm{C}$ for $5 \mathrm{~min}$, followed by 35 cycles at $94^{\circ} \mathrm{C}$ for $40 \mathrm{sec}, 58^{\circ} \mathrm{C}$ for $45 \mathrm{sec}, 72^{\circ} \mathrm{C}$ for $1 \mathrm{~min}$, followed by $72^{\circ} \mathrm{C}$ for $10 \mathrm{~min}$. The first PCR products were diluted 10 times with sterilized deionized water. The dilutions were used as template DNA for the second PCR reaction with the primer pairs NS31/AM1 (Van Tuinen et al., 1998; Hamady et al., 2008). The second PCR primer pairs was augmented with the 454 pyrosequencing adapters and 7-bp-long barcodes for multiplexing, resulting in the following constructs: 5 '-CGTATCGCCTCCCTCGCGCCATCAG (NNNNNNN)TTGGAGGGCAAGTCTGGTGCC-3'; and 5'-CTATGCGCCTTGCCAGCCCGCTCAGGTTTCCCGTAAGGCGCCG $\mathrm{AA}-3^{\prime}$ ( $\mathrm{A}$ and $\mathrm{B}$ adapters are underlined, the barcode is indicated by Ns in parenthesis and specific primers NS31 and AM1 are shown in italics).

The second PCR volume was $50 \mu \mathrm{L}$, containing $5.0 \mu \mathrm{L}$ $10 \times$ Ex Taq Buffer, $4.0 \mu \mathrm{L} 2.5 \mathrm{mmol} / \mathrm{L}$ dNTP mix, $2.0 \mu \mathrm{L}$ DNA template, $0.8 \mu \mathrm{L} 25 \mu \mathrm{mol} / \mathrm{L}$ each of forward and reverse primers, 0.5 U TakaRa Ex Taq (TaKaRa, Dalian, China) and $36.9 \mu \mathrm{L}$ sterilized of deionized water. The second PCR program was same with the first one. The second reaction products were run on a $1 \%(\mathrm{~W} / \mathrm{V})$ agarose gel, and the size of the amplicon was confirmed to be $550 \mathrm{bp}$. The band was extracted and purified using the kit QIAEX II Gel Extraction Kit (QIAGEN Sciences, Maryland) according to manufacturer instructions. Sequencing was performed by the Chinese National Human Genome Center in Shanghai.

\section{Sequence analysis and designation of OTUs}

The data was processed in accordance with the method of Lekberg et al. (2012) and Xiang et al. (2014). Sorting and trimming of sequences based on size ( $>450 \mathrm{bp}$ ) and quality ( $>5$ sequences) were performed by using the Mothur software (version 1.32.1, http://www.mothur.org). Singletons were removed from the alignments. Each alignment was roughly divided into preliminary operational taxonomic units (OTUs) using a 97\% similarity criterion. Sequence representatives from these preliminary OTUs were blasted manually against NCBI GenBank to identify non-AM fungal sequences that were subsequently removed from the data sets. Non-AM fungal sequences were defined either as having their closest match with Basidiomycota, or as having no known match. Identical sequences were then counted and removed to create 24 alignments with no duplicate sequences. OTUs were identified as clades with greater than $97 \%$ bootstrap support. To confirm OTU identity at the genus level, the blasted-based OTU identities were further verified by phylogenetic analysis incorporating reference sequences from both GenBank and MaarjAM databases (Xiang et al., 2014). Only sequences with $98 \%-100 \%$ coverage resulting in E-values close to zero (E-values $<1.0 \times 10^{-5}$ ) were reserved for further analysis (Lekberg et al., 2012).

\section{Statistical analysis}

The plant Shannon-Weiner diversity index was calculated by Microsoft $\circledast$ Excel 2010, using the equation:

$H^{\prime}=-\sum P_{i}\left(\log _{e} P_{i}\right)$

$P_{i}=n_{\mathrm{i}} / \mathrm{N}$

where, $n_{i}$ is the number of individuals of species $i$, and $N$ is the total number of individuals in all species. The AMF diversity of chao1 and the Shannon-Wiener index was analyzed by Mothur software (version 1.32.1). All discriminative statistics were performed by using the SPSS software 17.0. The effect of categorical factors, i.e., heavy metal, soil physical and chemical characteristics, plant diversity and AMF diversity index, were carried out using one-way analysis of variance (ANOVA). The total and bioavailable As concentrations in combination with other soil chemical properties, such as Cd, Ni, SOC, AP, C/N, and $\mathrm{pH}$ were used as environmental variables in the Redundancy analysis (RDA), which was carried out using the CANOCO 4.5 software (Microcomputer Power, Ithaca, USA).

\section{Results}

\subsection{Chemical attributes of soil samples}

The Realgar mining area was polluted by multiple heavy metals such as $\mathrm{Cd}, \mathrm{Ni}$, as well as As (Table 1). The total As concentration in soils ranged from 315.49 to $21,160.80 \mathrm{mg} / \mathrm{kg}$. The bioavailable As concentration was from 23.14 to $119.30 \mathrm{mg} / \mathrm{kg}$. The sampling site S5 exhibited the highest total As, but with the lowest bioavailable As concentration. According to the national soil quality standard of China (GB15618-2008), the total As concentration of all six sampling sites exceeded 11-845 folds of the contamination grade II (25 mg/kg, pH > 7.5) in dry soil of agricultural land, the Cd concentration $(0.80 \mathrm{mg} / \mathrm{kg}, \mathrm{pH}>7.5)$ was $167-892$ folds, and the Ni concentration $(100 \mathrm{mg} / \mathrm{kg}, \mathrm{pH}>7.5)$ was $1.4-1.6$ folds above the national soil quality standard. The concentrations of all other heavy metal elements were well below contamination level in all the sampling sites. Soil organic carbon (SOC) and $\mathrm{pH}$ were all higher in site REF than other five sites, while the opposite was recorded for $\mathrm{C} / \mathrm{N}$ ratio. There was no obvious distribution pattern of soil AP concentrations among the sampling sites and the highest concentration was in site $\mathrm{S} 5$ while the lowest in S1. 


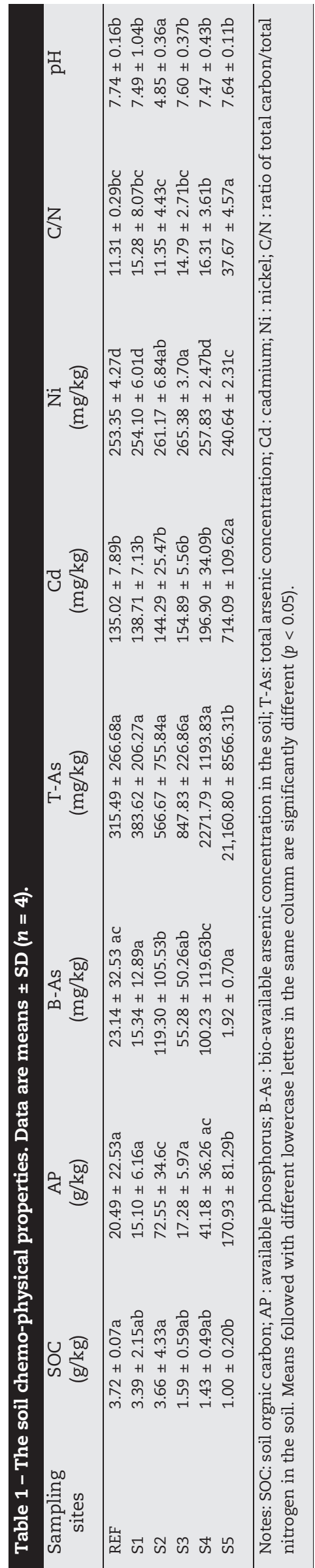

\subsection{Overall pyrosequencing information}

The rarefaction analysis indicated that our sampling intensity was sufficient to identify the great majority of AM fungal OTUs in all the samples (Fig. 2).

A total of 116,334 sequences were conformed to initial quality assessment. There were 31,045 sequences which matched with Glomeromycota in GenBank. The remaining sequences were either of non-Glomeromycotan origin (predominately Basidiomycetes) or poor quality (fewer than 5 sequences). A total of 106 OTUs were obtained in all samples (Fig. 3). The obtained AM fungal sequences were grouped into 27 groups based on phylogenetic analysis and blast searches. In total, eleven AM fungal genera were identified. Twelve groups belong to the Glomus, four to Rhizophagus, two to Paraglomus, two to Arcgaeospora and other seven groups belong to Funneliformis, Ambispora, Diversispora, Claroideoglomus, Scutellopora, Gigaspora, and Acaulospora respectively. The great majority of sequences belong to Glomus group F (10 OTUs). Only 8 groups could be identified to species level, and they were Rhizophagus intraradices, Funneliformis mosseae, Glomus viscosum, Glomus indicum, Glomus macrocarpum, Claroideoglomus clarodeum, Gigaspora margarita and Paraglomus brasilianum.

\section{AMF colonization and community composition}

Mycorrhizal colonization rates ranged from $12.27 \%$ to $33.28 \%$ (Table 2). The highest colonization was recorded in REF, and the lowest was found in sample S2. There were no significant differences among samples except sample REF and sample S2.

Across the sampling sites the universal genera were Glomus, Rhizophagus and Claroideoglomus (Fig. 4). Glomus was the most frequent genus in sampling sites REF, S1, S4 and S5. Rhizophagus was the most frequent genus in sampling site S2 and S3. F. mosseae occurred in all other sampling sites, except S2 and S5. Paraglomus appeared in sampling sites S3, S4 and S5. Ambispora appeared in sampling sites S2 and S5. Scutellopora was only observed in sampling site S1.

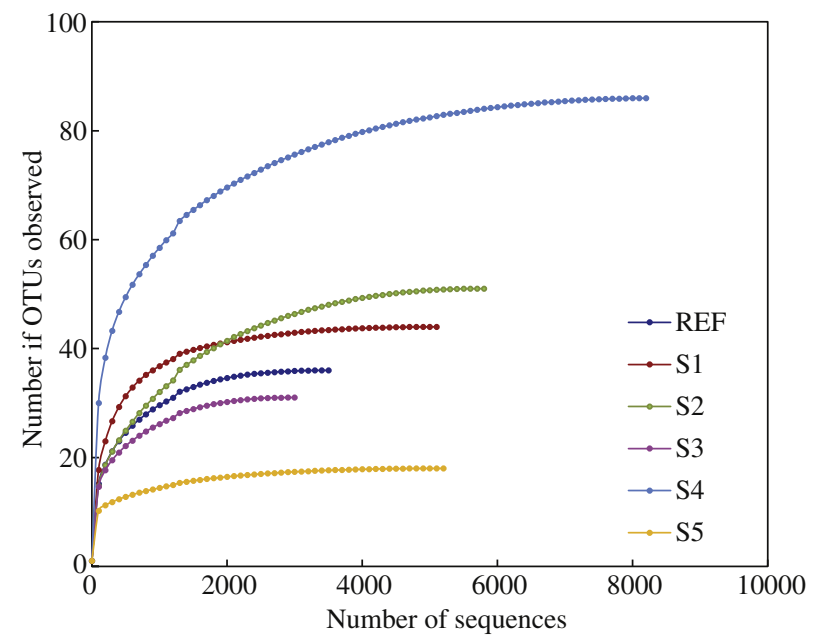

Fig. 2 - Rarefaction curves depicting the sequence number on the number of operational taxonomic units (OTUs) identified from all six sampling sites. REF, S1, S2, S3, S4 and S5 represent the six sampling sites. 


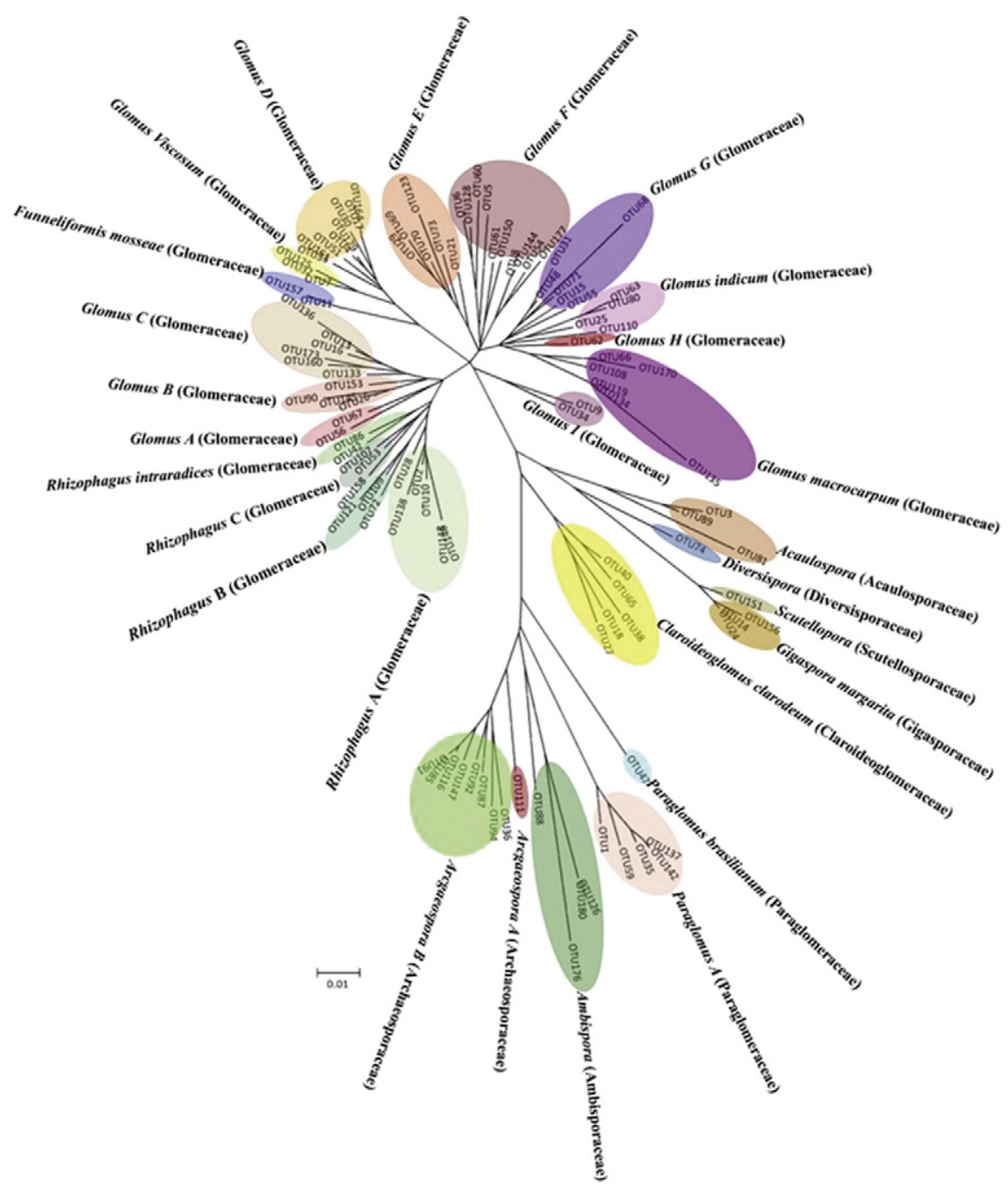

Fig. 3 - Phylogenetic tree showing the representative sequences of operational taxonomic units (OTUs) of arbuscular mycorrhizal fungi (AMF).

\subsection{AMF and plant diversity}

Except for S4, the estimated AMF diversity (Shannon-Wiener index) generally decreased with the increased total As concentrations (Table 2). The OTU richness index (chao 1) showed the same trend with diversity. S4 exhibited the highest richness index, which was significantly different from REF and S5. The plant community composition among all sampling sites was largely different. The dominant plant species on site REF were
Digitaria violascens Link, Eclipta prostrata and Veronica didyma Tenore. On S1, dominant plant species were Digitaria ciliaris (Retz.) Koel, Herba seu Radix Amaranthi, Eleusine indica (L.) Gaertn and Solanum nigrum L. Sites S2 and S5 were dominated by Miscanthus floridulu (Labnll.) Warb. S3 was dominated by Allium senescens, Clinopodium chinense (Benth.) O.Ktze and Poa annua L., while S4 was dominated by Paspalum paspaloides (Michx.) Scribn. The plant Shannon-Wiener diversity index $\left(\mathrm{H}^{\prime}\right)$ was highest in site S1, and lowest in site S2. However, no significant correlation

Table 2 - The mycorrhizal colonization rate of plant roots and the biodiversity index of arbuscular mycorrhizal fungi (AMF) and plants in different sampling sites. Data are means \pm SD $(n=4)$.

\begin{tabular}{lcccc} 
Sampling sites & Mycorrhizal colonization rate (\%) & AMF Shannon-Wiener index & Chao 1 & Plant Shannon-Wiener index \\
\hline REF & $33.28 \pm 11.09 \mathrm{a}$ & $1.73 \pm 0.42 \mathrm{~b}$ & $13.42 \pm 6.31 \mathrm{a}$ & $1.30 \pm 0.43 \mathrm{ac}$ \\
S1 & $29.04 \pm 16.67 \mathrm{ab}$ & $1.61 \pm 0.43 \mathrm{bc}$ & $16.18 \pm 6.77 \mathrm{a}$ & $1.71 \pm 0.34 \mathrm{a}$ \\
S2 & $12.27 \pm 9.88 \mathrm{~b}$ & $1.36 \pm 0.53 \mathrm{bc}$ & $14.16 \pm 10.99 \mathrm{a}$ & $0.73 \pm 0.28 \mathrm{~b}$ \\
S3 & $17.38 \pm 3.91 \mathrm{ab}$ & $1.28 \pm 0.38 \mathrm{bc}$ & $9.57 \pm 1.77 \mathrm{a}$ & $1.22 \pm 0.29 \mathrm{c}$ \\
S4 & $30.05 \pm 19.56 \mathrm{ab}$ & $2.72 \pm 0.13 \mathrm{a}$ & $38.37 \pm 5.76 \mathrm{a}$ & $0.95 \pm 0.24 \mathrm{bc}$ \\
S5 & $30.52 \pm 15.43 \mathrm{ab}$ & $0.93 \pm 0.61 \mathrm{c}$ & $6.18 \pm 0.82 \mathrm{~b}$ & $1.30 \pm 0.04 \mathrm{c}$ \\
\hline
\end{tabular}

Notes: Means followed with different lowercase letters in the same column are significantly different $(p<0.05)$. 

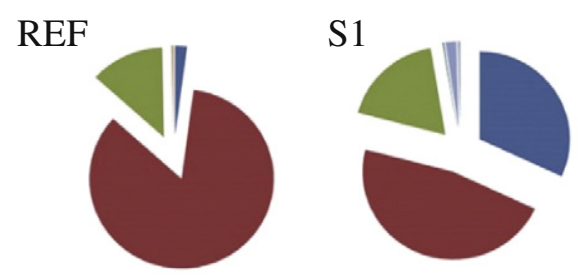

S3

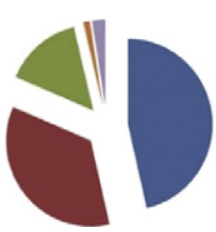

S4

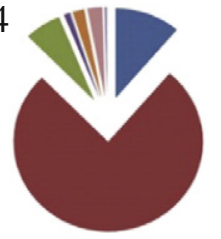

S2

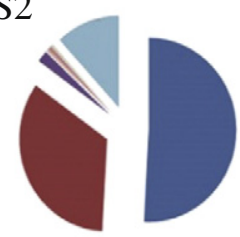

S5

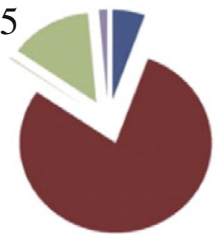

Rhizophagus

Glomus

Funneliformis mosseae

Acaulospora

Diversispora

Claroideoglomus clarodeum

Scutellopora

Gigaspora margarita

Ambispora

- Paraglomus

Archaeospora

Fig. 4 - Proportion of total read numbers of operational taxonomic units (OTUs) grouped by arbuscular mycorrhizal fungal (AMF) genus in the Realgar mining areas. REF, S1, S2, S3, S4 and S5 represent the six sampling sites.

was found between the Shannon-Wiener index of AMF and plants (data not shown).

\subsection{Relationships between AMF parameters and soil properties}

RDA analysis showed that the total As (T-As), Cd, and pH had significant effects on the AMF community structure, among which, $\mathrm{pH}$ was the most prominent factor, followed by $\mathrm{T}-\mathrm{As}$, and $\mathrm{Cd}$ in the Realgar mining area (Fig. 5). These variables explained $84 \%$ of the variation in the AMF community composition. Soil $\mathrm{pH}$ had the greatest impact, explaining $36 \%$ of the explained variation in the dataset. The total As and Cd explained $19 \%$ and $28 \%$ of the variation respectively. Pearson correlation analysis showed that there was a negative correlation between the AMF Shannon-Wiener index and the total As concentrations $\left(r=-0.438^{*}, P<0.05\right)$.

\section{Discussion}

In the present study, a total of $11 \mathrm{AM}$ fungal genera were identified in the Realgar mining area and the number of AMF genera varies from 4 to 8 in each sampling site. More AMF genera were found in our study than those in Brazil gold mining areas contaminated by As (Schneider et al., 2012), where totally 6 genera were found by morphological identification. The distinct AMF community composition could attribute to distinct plant communities and soil characteristics, and certainly also different methodologies for identification of AM fungi. The plant community composition might have direct effects on the composition of associated AMF communities, because of distinct plant physiological traits (Eom et al., 2000). The As concentration in site S4 was as high as $2271.79 \mathrm{mg} / \mathrm{kg}$, while the AMF alpha diversity was also the highest among all the sampling sites. This may be attributed to the specific dominant plant, Paspalum paspaloides (Michx.). Scribn, on site S4. P.paspaloides is perennial weed with fibrous roots, which has a strong ability to adapt to adverse environments. Once these plants are successfully colonized by AMF, they could serve as a relatively safe and stable habitat. These traits of the host plants could potentially sustain a relatively high AMF diversity.

The morphological identification method had obvious limitations to study AMF biodiversity, as reliable results always require the proficiency of the identifier, and the sporulation of AMF may depend on environmental conditions. Under certain circumstance or during certain seasons of the year, some AMF may not produce spores at all (Redecker et al., 2003). By contrast, molecular identification techniques provided a powerful tool to identify AMF in any given roots or soil samples without the need for spores. Therefore, the 454-pyrosequencing methodology employed here was likely to provide more accurate information

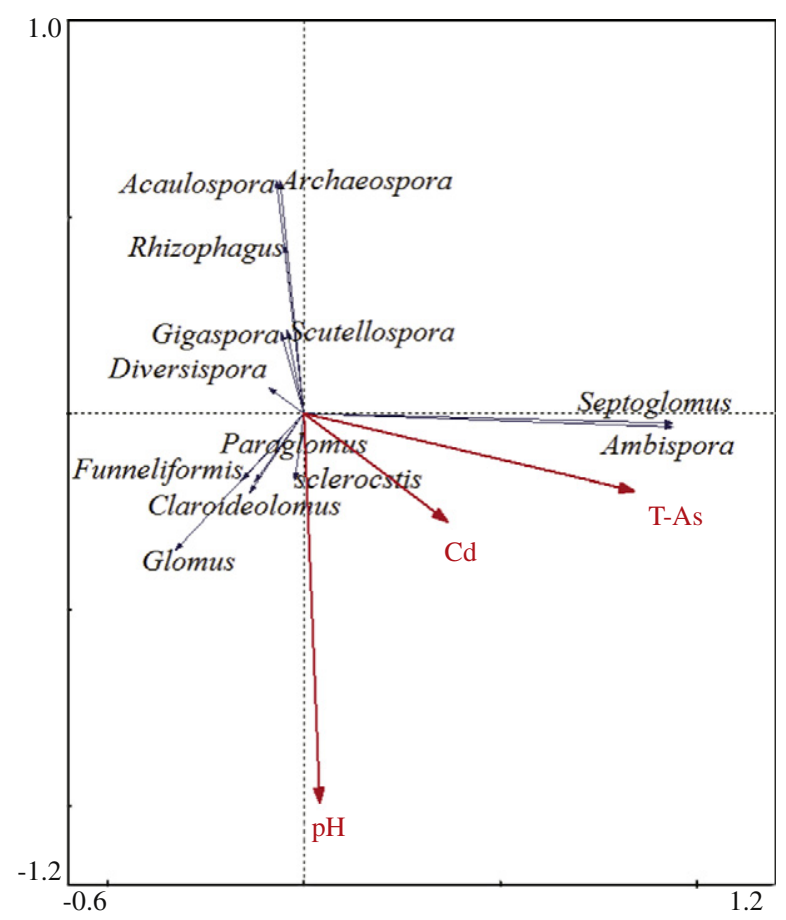

Fig. 5 - Redundancy analysis biplot of the community structure of arbuscular mycorrhizal fungi (AMF) with soil characteristics. T-As, total arsenic concentration in soil. 
of AMF biodiversity than the morphological identification method.

Phylogenetic analysis indicated that the predominant genus in the Realgar mining area was Glomus, followed by Rhizophagus and Claroideoglomus. Compared to other genera, Glomus exhibits a higher sporulation rate, thus enable them to recover more rapidly and could be better adapted to disturbed environments (Daniell et al., 2001; Whitfield et al., 2004). Besides, the Glomeraceae colonize via mycelium or mycorrhizal root fragments (Biermann and Linderman, 1983; Daniell et al., 2001). Once plant roots were colonized by Glomus species, the plants could benefit from the symbiotic association and became more competitive, and also provide favorite habitats for the colonizers (Vallino et al., 2006). Differently, Schneider et al (2012) found that the predominant species in the Brazil gold mining areas were Paraglomus, followed by Acaulospora and Glomus. The possible reason for the different predominant AMF species between the two mining sites may be due to the different vegetation systems. Since AMF are obligatory biotrophic, the host plants can largely affect the AMF structure and composition (Del Val et al., 1999), and also the occurrence of infective AMF propagules (Smith et al., 2010a; da Silva et al., 2005; Hildebrandt et al., 2007; Nogueira et al., 2007). In the mycorrhizal mutualism, partners that offer the best rate of exchange are rewarded, and the plant species were clever enough to choose their own beneficial AMF mycoflora (Wei et al., 2015), so does the AM fungus. We could suppose that Scutellopora could not well cooperate with most of the host plants in the realgar mining areas and therefore was less abundant.

In our study, we found that Acaulospora had been observed only in site S2 and S4. The dominant AMF genus in site S2 was Rhizophagus and the mycorrhizal colonization rate was the lowest. Among all sampling sites, the soil $\mathrm{pH}(\mathrm{pH}=4.85)$ in site S2 was the lowest, which was most likely due to the discharge of acidic wastes from a factory nearby. Some research had shown that soil $\mathrm{pH}$ had significant influences on AMF community composition and spore density from natural ecosystems to crop production systems (Tchabi et al., 2008; Xiang et al., 2014). It has been reported that certain AMF genera prefer to acid soils while some others could tolerate a wider range of $\mathrm{pH}$ (Maia and Trufem, 1990). For example, Glomus prefers neutral or slightly alkaline pH (Zambolim and Siqueira, 1985; Schenck and Siqueira, 1987), while Gigaspora, Entrophospora, Sclerocystis favor acid soils (da Silva et al., 2005). Soil pH could affect spore germination (Green et al., 1976; Hepper, 1984), hyphal growth and formation (Abbott and Robson, 1985), thus, ultimately influence the quantity and quality of AMF colonization and alter the community composition (Robson and Abbott, 1989; Coughlan et al., 2000). We suppose that in the Realgar mining area low $\mathrm{pH}$ suppressed the development of local plants, and indirectly affected the AMF biodiversity, as the plant Shannon-Wiener richness index in sampling site S2 was lowest (0.73) and was significantly different from other sites except site S4.

Unsurprisingly, there was a negative correlation between AMF species richness with T-As. This suggested that high As concentrations can exert a selective effect on the AMF populations, and favor more adaptive species. Different AMF species could exhibit different susceptibility to As contaminations, even with the same host plant under a given soil condition. For example, Yu et al. (2010) found that the root colonization rates of maize plants were significantly different, when inoculated with three different AMF species in the same As contaminated soil. In their research, Glomus mosseae showed the highest root colonization rate (17.4\%-81.6\%), followed by Glomus etunicatum $(5.6 \%-$ $44.3 \%$ ) and Glomus constrictum (1.8\%-16.8\%). Anyway, AMF had a widely recognized role in helping plant to adapt to As contaminated soils, by reducing $\mathrm{As}(\mathrm{V})$ influx into excised plant roots (Gonzalez-Chavez et al., 2002), mitigating oxidative stress of the plant caused by the As contamination (Yu et al., 2009; Garg and Singla, 2012), and influencing the distribution and the speciation of As in plants (Yu et al., 2009; Chen et al., 2012; Zhang et al., 2015). In the Shimen Realgar mining area, there are potentially some As tolerant AMF strains after a long-term adaptation to As contamination, while those AMF strains could be ideal candidates for bioremediation of the contaminated environments. Future work can focus on isolating AMF strains from the As contaminated soils, and identifying their potential role in bioremediation practice.

A variety of environmental factors could influence the AMF community structure, and among them, heavy metal contaminations $(\mathrm{Pb}, \mathrm{Zn}, \mathrm{Cu}$ and $\mathrm{Cd}$ ) have been found to be important predictors (Yang et al., 2015). In addition to As, we also found that the Cd concentrations had a significant effect on the AMF community structure (Fig. 5). This may be due to the high Cd concentrations (from 135.02 to $714.09 \mathrm{mg} / \mathrm{kg}$ ) exerted a harmful effects on the AMF (Wu et al., 2010). Actually, the soils in the research area exhibited a typical combined contamination by heavy metals (Table 1). The observed variation in AMF communities among sampling sites is most likely the results of combined contamination, but the underlying mechanism is largely unresolved and need further investigations.

We observed no significant correlation between the AMF and plant diversity in the Realgar mining area. Due to the fact that the mining activities just ceased completely in 2011, the plant community was still in the early stage of secondary succession, and the plant diversity was generally low. As reported by Oehl et al. (2010) and Xiang et al. (2014), both biotic and abiotic factors can influence the relationship between AMF and plant biodiversity, and a long-term disturbed ecosystem with low plant diversity can potentially maintain a reasonably high AMF diversity. Therefore, it was not surprising to find irrelevant relationships between plant and AMF populations. All in all, the soil environment in the mining area is quite complex, systematic studies are still needed to tease out specific influencing factors and their relative importance in shaping AMF communities.

\section{Conclusions}

By using the 454-pyrosequencing technique, a total of $11 \mathrm{AM}$ fungal genera were identified in the Realgar mining areas. Glomus, Rhizophagus and C. clarodeum were present in all the sampling sites, and Glomus was the dominant genus. Soil $\mathrm{pH}$, total As and Cd concentrations were the key environmental factors influencing AMF community structure in the research area. The total As concentration showed a negative impact on the AMF species richness. High As concentrations can exert a selective effect on the AMF populations, and favor more adaptive species, which supported the possibility of screening tolerant AMF strains for future soil bioremediation practices. 


\section{Acknowledgments}

This work was supported by the National Natural Science Foundation of China (Nos. 41101246, 41471219) and the National Key Technology R\&D Program of China (No. 2012BAC25B03). The authors thank Professor Lixin Zhang from Nanjing University for helping us to identify the plant species.

\section{REF E R E N C E S}

Abbott, L.K., Robson, A.D., 1985. The effect of soil pH on the formation of VA mycorrhizas by two species of Glomus. Soil Res. 23 (2), 253-261.

Beesley, L., Dickinson, N., 2010. Carbon and trace element mobility in an urban soil amended with green waste compost. J. Soil Sediment. 10 (2), 215-222.

Biermann, B., Linderman, R.G., 1983. Use of vesicular-arbuscular mycorrhizal roots, intraradical vesicles and extraradical vesicles as inoculum. New Phytol. 95 (1), 97-105.

Chen, B.D., Xiao, X.Y., Zhu, Y.G., Smith, F.A., Xie, Z.M., Smith, S.E., 2007. The arbuscular mycorrhizal fungus Glomus mosseae gives contradictory effects on phosphorus and arsenic acquisition by Medicago sativa Linn. Sci. Total Environ. 379 (2), 226-234

Chen, X., Li, H., Chan, W.F., Wu, C., Wu, F., Wu, S., Wong, M.H., 2012. Arsenite transporters expression in rice (Oryza sativa L.) associated with arbuscular mycorrhizal fungi (AMF) colonization under different levels of arsenite stress. Chemosphere 89, 1248-1254.

Coughlan, A.P., Dalpé, Y., Lapointe, L., Piché, Y., 2000. Soil $\mathrm{pH}$-induced changes in root colonization, diversity, and reproduction of symbiotic arbuscular mycorrhizal fungi from healthy and declining maple forests. Can. J. For. Res. 30 (10), 1543-1554.

da Silva, G.A., Trufem, S.F.B., Júnior, O.J.S., Maia, L.C., 2005. Arbuscular mycorrhizal fungi in a semiarid copper mining area in Brazil. Mycorrhiza 15 (1), 47-53.

Daniell, T.J., Husband, R., Fitter, A.H., Young, J.P., 2001. Molecular diversity of arbuscular mycorrhizal fungi colonising arable crops. FEMS Microbiol. Ecol. 36 (2-3), 203-209.

Del Val, C., Barea, J.M., Azcón-Aguilar, C., 1999. Diversity of arbuscular mycorrhizal fungus populations in heavy-metal-contaminated soils. Appl. Environ. Microbiol. 65 (2), 718-723.

Dhuldhaj, U.P., Yadav, I.C., Singh, S., Sharma, N.K., 2013. Microbial Interactions in the Arsenic Cycle: Adoptive Strategies and Applications in Environmental Management. Rev. Environ. Contam. Toxicol. 224. Springer, New York, pp. 1-38

Dong, Y., Zhu, Y.G., Smith, F.A., Wang, Y.S., Chen, B.D., 2008. Arbuscular mycorrhiza enhanced arsenic resistance of both white clover (Trifolium repens Linn.) and ryegrass (Lolium perenne L.) plants in an arsenic-contaminated soil. Environ. Pollut. 155 (1), 174-181.

Eom, A.H., Hartnett, D.C., Wilson, G.W.T., 2000. Host plant species effects on arbuscular mycorrhizal fungal communities in tallgrass prairie. Oecologia 122 (3), 435-444.

Fitz, W.J., Wenzel, W.W., 2002. Arsenic transformations in the soil-rhizosphere-plant system: fundamentals and potential application to phytoremediation. J. Biotechnol. 99 (3), 259-278.

Garg, N., Singla, P., 2012. The role of Glomus mosseae on key physiological and biochemical parameters of pea plants grown in arsenic contaminated soil. Sci. Hortic. 143, 92-101.

Gonzalez-Chavez, C., Harris, P.J., Dodd, J., Meharg, A.A., 2002. Arbuscular mycorrhizal fungi confer enhanced arsenate resistance on Holcus lanatus. New Phytol. 155 (1), 163-171.
Green, N.E., Graham, S.O., Schenck, N.C., 1976. The influence of pH on the germination of vesicular-arbuscular mycorrhizal spores. Mycologia 929-934.

Hamady, M., Walker, J.J., Harris, J.K., Gold, N.J., Knight, R., 2008. Error-correcting barcoded primers for pyrosequencing hundreds of samples in multiplex. Nat. Methods 5 (3), 235-237.

Hepper, C.M., 1984. Regulation of spore germination of the vesicular-arbuscular mycorrhizal fungus Acaulospora laevis by soil pH. Trans. Br. Mycol. Soc. 83 (1), 154-156.

Hildebrandt, U., Regvar, M., Bothe, H., 2007. Arbuscular mycorrhiza and heavy metal tolerance. Phytochemical 68 (1), 139-146.

Hudson-Edwards, K.A., Santini, J.M., 2013. Arsenic-microbe-mineral interactions in mining-affected environments. Minerals 3 (4), 337-351.

Lee, J., Lee, S., Young, J.P.W., 2008. Improved PCR primers for the detection and identification of arbuscular mycorrhizal fungi. FEMS Microb. Ecol. 65 (2), 339-349.

Lekberg, Y., Schnoor, T., Kjøller, R., Gibbons, S.M., Hansen, L.H., et al., 2012. 454-sequencing reveals stochastic local reassembly and high disturbance tolerance within arbuscular mycorrhizal fungal communities. J. Ecol. 100 (1), 151-160.

Li, T., Hu, Y.J., Hao, Z.P., Li, H., Wang, Y.S., Chen, B.D., 2013. First cloning and characterization of two functional aquaporin genes from an arbuscular mycorrhizal fungus Glomus intraradices. New Phytol. 197 (2), 617-630.

Liu, Y., Zhu, Y.G., Chen, B.D., Christie, P., Li, X.L., 2005. Yield and arsenate uptake of arbuscular mycorrhizal tomato colonized by Glomus mosseae BEG167 in As spiked soil under glasshouse conditions. Environ. Int. 31 (6), 867-873.

Lorenz, N., Hintemann, T., Kramarewa, T., Katayama, A., Yasuta, T., Marschner, P., et al., 2006. Response of microbial activity and microbial community composition in soils to long-term arsenic and cadmium exposure. Soil Biol. Biochem. 38 (6), 1430-1437.

Maia, L.C., Trufem, S.F.B., 1990. Vesicular-arbuscular mycorrhizal fungi in cultivated soils in Pernambuco State, Brazil. Rev. Bras. Bot. 13, 89-95.

Meharg, A.A., Cairney, J.W.G., 1999. Co-evolution of mycorrhizal symbionts and their hosts to metal-contaminated environments. Adv. Ecol. Res. 30, 69-112.

Meharg, A.A., Hartley-Whitaker, J., 2002. Arsenic uptake and metabolism in arsenic resistant and nonresistant plant species. New Phytol. 154 (1), 29-43.

Mukhopadhyay, R., Rosen, B.P., Phung, L.T., Silver, S., 2002. Microbial arsenic, from geocycles to genes and enzymes. FEMS Microbiol. Rev. 26 (3), 311-325.

Nelson, D.W., Sommers, L.E., 1996. Total carbon, organic carbon, and organic matter. Meth. Soil Anal. 3 (3), 961-1010.

Nogueira, M.A., Nehls, U., Hampp, R., Poralla, K., Cardoso, E.J.B.N., 2007. Mycorrhiza and soil bacteria influence extractable iron and manganese in soil and uptake by soybean. Plant Soil 298 (1-2), 273-284.

Oehl, F., Laczko, E., Bogenrieder, A., Stahr, K., BÖsch, R., van der Heijden, M., et al., 2010. Soil type and land use intensity determine the composition of arbuscular mycorrhizal fungal communities. Soil Biol. Biochem. 42, 724-738.

Olsen, S.R., 1954. Estimation of available phosphorus in soils by extraction with sodium bicarbonate. Circular 939. United States Department Of Agriculture, Washington, pp. 1-18.

Phillips, J.M., Hayman, D.S., 1970. Improved procedures for clearing roots and staining parasitic and vesicular-arbuscular mycorrhizal fungi for rapid assessment of infection. Trans. Br. Mycol. Soc. 55 (1), 158-IN18.

Redecker, D., Hijri, I., Wiemken, A., 2003. Molecular identification of arbuscular mycorrhizal fungi in roots: perspectives and problems. Folia Geobot. 38 (2), 113-124.

Rillig, M.C., 2004. Arbuscular mycorrhizae and terrestrial ecosystem processes. Ecol. Lett. 7 (8), 740-754. 
Robson, A.D., Abbott, L.K., 1989. The effect of soil acidity on microbial activity in soils. In: Robson, A.D. (Ed.), Soil Acidity and Plant Growth. Academic Press Australia, Marrickville, New South Wales, pp. 139-165.

Schenck, N.C., Siqueira, J.O., 1987. Ecology of VA mycorrhizal fungi in temperate agroecosystems. In: Sylvia, D.M., Hung, L.L., Graham, J.H. (Eds.), Seventh North American Conference on Mycorrhizae, Gainesville, Fla. Mycorrhizae in the Next Decade, pp. 2-4.

Schneider, J., Stürmer, S.L., Guilherme, L.R.G., de Souza Moreira, F.M., de Sousa Soares, C.R.F., 2012. Arbuscular mycorrhizal fungi in arsenic-contaminated areas in Brazil. J. Hazard. Mater. 262, 1105-1115.

Smith, S.E., Read, D.J., 2008. Mycorrhizal Symbiosis[M]. 3rd ed. Academic Press, New York, pp. 11-32.

Smith, E., Naidu, R., Alston, A.M., 1998. Arsenic in the soil environment, a review. Adv. Agron. 64, 149-195.

Smith, S.E., Christophersen, H.M., Pope, S., Smith, F.A., 2010a. Arsenic uptake and toxicity in plants, integrating mycorrhizal influences. Plant Soil 327 (1-2), 1-21.

Smith, S.E., Facelli, E., Pope, S., Smith, F.A., 2010b. Plant performance in stressful environments, interpreting new and established knowledge of the roles of arbuscular mycorrhizas. Plant Soil 326 (1-2), 3-20.

Tchabi, A., Coyne, D., Hountondji, F., Lawouin, L., Wiemken, A., Oehl, F., 2008. Arbuscular mycorrhizal fungal communities in sub-Saharan Savannas of Benin, West Africa, as affected by agricultural land use intensity and ecological zone. Mycorrhiza 18 (4), 181-195.

Vallino, M., Massa, N., Lumini, E., Bianciotto, V., Berta, G., Bonfante, P., 2006. Assessment of arbuscular mycorrhizal fungal diversity in roots of Solidago gigantea growing in a polluted soil in Northern Italy. Environ. Microbiol. 8 (6), 971-983.

van der Heijden, M.G.A., Klironomos, J.N., Ursic, M., Moutoglis, P., Streitwolf-Engel, R., Boller, T., 1998. Mycorrhizal fungal diversity determines plant biodiversity, ecosystem variability and productivity. Nature 396 (6706), 69-72.

Van Tuinen, D., Jacquot, E., Zhao, B., Gollotte, A., GianinazziPearson, V., 1998. Characterization of root colonization profiles by a microcosm community of arbuscular mycorrhizal fungi using 25S rDNA-targeted nested PCR. Mol. Ecol. 7 (7), 879-887.

Wang, P., Sun, G., Jia, Y., Meharg, A.A., Zhu, Y., 2014. A review on completing arsenic biogeochemical cycle, microbial volatilization of arsines in environment. J. Environ. Sci. 26 (2), 371-381.
Wei, Y., Chen, Z., Wu, F., Hou, H., Li, J., Shangguan, Y., et al., 2015. Molecular diversity of arbuscular mycorrhizal fungi at a largescale antimony mining area in southern China. J. Environ. Sci. $29,18-26$.

Whitfield, L., Richards, A.J., Rimmer, D.L., 2004. Relationships between soil heavy metal concentration and mycorrhizal colonisation in Thymus polytrichus in northern England. Mycorrhiza 14 (1), 55-62.

Willis, A., Rodrigues, B.F., Harris, P.J.C., 2013. The ecology of arbuscular mycorrhizal fungi. Crit. Rev. Plant Sci. 32 (1), 1-20.

Wu, F.Y., Bi, Y.L., Leung, H.M., Ye, Z.H., Lin, X.G., Wong, M.H., 2010. Accumulation of $\mathrm{As}, \mathrm{Pb}, \mathrm{Zn}, \mathrm{Cd}$ and $\mathrm{Cu}$ and arbuscular mycorrhizal status in populations of Cynodon dactylon grown on metal-contaminated soils. Appl. Soil Ecol. 44 (3), 213-218.

Xiang, D., Verbruggen, E., Hu, Y., Veresoglou, S.D., Rillig, M.C., Zhou, W., et al., 2014. Land use influences arbuscular mycorrhizal fungal communities in the farming-pastoral ecotone of northern China. New Phytol. 204 (4), 968-978.

Yang, Y., Song, Y., Scheller, H.V., Ghosh, A., Ban, Y., Chen, H., et al., 2015. Community structure of arbuscular mycorrhizal fungi associated with Robinia pseudoacacia in uncontaminated and heavy metal contaminated soils. Soil Biol. Biochem. 86, 146-158.

Yu, Y., Zhang, S.Z., Huang, H.L., Luo, L., Wen, B., 2009. Arsenic accumulation and speciation in maize as affected by inoculation with arbuscular mycorrhizal fungus Glomus mosseae. J. Agric. Food Chem. 57, 3695-3701.

Yu, Y., Zhang, S., Huang, H., Wu, N., 2010. Uptake of arsenic by maize inoculated with three different arbuscular mycorrhizal fungi. Commun. Soil Sci. Plant. 6, 735-743.

Zambolim, L., Siqueira, J.O., 1985. Importancia e potencial das associacoes micorrizicas para a agricultura. DocumentosEmpresa de Pesquisa Agropecuaria de Minas Gerais (Brazil). no. 26.

Zhang, X., Ren, B.H., Wu, S.L., Sun, Y.Q., Lin, G., Chen, B.D., 2015. Arbuscular mycorrhizal symbiosis influences arsenic accumulation and speciation in Medicago truncatula L. in arsenic-contaminated soil. Chemosphere 119, 224-230.

Zhu, Y.G., Yoshinaga, M., Zhao, F.J., Rosen, B.P., 2014. Earth abides arsenic biotransformations. Ann. Rev. Earth Planet Sci. 42, 443-467. 